\title{
Conditioning Factors of Late Payment of Trade Credit
}

\author{
Claudinê Jordão de Carvalho ${ }^{\dagger}$ \\ Federal University of Uberlândia
}

\begin{abstract}
This article presents new evidence on the practice of financial delinquency of trade credits. The low level of punctuality in payments to suppliers can negatively affect the liquidity of the lender and be transmitted to all companies in the value chain, creating uncertainties in the business environment. The aim is to identify and analyse the factors responsible for delay in payment to suppliers. A survey with 554 brazilian companies located in the provinces of Minas Gerais and São Paulo enable application of the model of ordered logit regression analysis. The dependent variable is the financial delinquency level of companies that do or do not delay the payment of duties, and the independent variables are the demographic, financial, and operational inherent demand for financing and moral hazard. The results show that companies with more short-term debts, beginner on its business activities, and that have a higher proportion of customers who pay their credit purchase on time are more likely to delay their obligations to suppliers.
\end{abstract}

Keywords: Hidden information. Information asymmetry. Financial crime. Purchase on credit.

*Author for correspondence:

t. Doctor in Administration Institution: Federal University of

Uberlândia

Address: Av. Brasil, 3100

- Uberlândia - SP - Brazil

E-mail: claudinejordao@gmail.com

Telephone: (34) 3232-4890

Note from the Editor: The article was accepted by Emerson Mainardes. 


\section{INTRODUCTION}

he delay of payments in commercial transactions between companies is not a

recent phenomenon in the real economy, and it can have a negative impact not only on the performance of companies that grant the trade credit (TC), but also on the reputation of the offenders (PETERSEN; RAJAN, 1994) and the confidence level of the business environment. This event is the realization of hidden action of asymmetric information (AKERLOF, 1970) in contracts.

Howorth and Reber (2003) and Carvalho and Schiozer (2012) found that, on average, $80 \%$ of British and Brazilian Micro and Small Enterprises (hereafter MSEs) practice this type of financial delinquency. The delinquency is the lack of timely payment of the value of the TC. This event can be both financial — late payments — or by defaulting or full insolvency (HOWORTH; REBER, 2003). The TC contracts embed aspects of agency theory as asymmetric information and moral hazard (AKERLOF, 1970; JENSEN; MECKLING, 1976) and transactions cost (WILLIAMSON, 1979) inherent in loan demand.

After all, why do companies that receive TC delay payments to suppliers? The answer to this question is not clear in the literature of corporate finance. From this context, and considering the lack of empirical studies and databases systematised and available on this subject in Brazil, this research seeks to fill this gap by answering the following research question:

What are the organizational characteristics of companies not listed on the stock exchange associated with delinquent behavior of late payment to suppliers?

The main objective of this study is to analyses whether demographic, operational, and financial factors are associated, significantly or not, to the practice of late payments of commercial credits in companies not listed in the stock exchange.

The results show that companies with more short-term debts, beginner on its business activities and that have a higher proportion of customers who pay their credit purchase on time are more likely to delay their obligations to suppliers.

This study contributes to the literature of short-term corporate finance by increasing knowledge on the management of working capital and, more specifically, this type of delinquency.

The results provide important implications in the companies' form of managing the grant of TC. The factors responsible for late payment may be considered, for example, to 
review and update models of intercompany credit risk evaluation scores and also by class associations to formulate financial education and training programmes for managers. They may also be used by authorities to formulate public policies aimed at removing institutional credit market frictions to improve access to funding sources and reduce the cost of capital transactions of companies not listed in the stock exchange.

\section{THEORETICAL AND EMPIRICAL FRAMEWORK}

The theoretical perspectives of agency and transaction costs support the development of this study.

\subsection{TRANSACTION COSTS}

A firm can be understood as a nexus of contracts in which there are two types of costs: of production that takes place within it, and the transaction with third parties (COASE, 1937). A transaction occurs when a good or service is transferred across technologically distinct interfaces (WILLIAMSON, 1981). According to this theoretical perspective, firms exist because it is more economical to carry out a transaction internally than turn to the free market. Thus, the decision to delay the payment of TC can be explained based on the trade-off between the transaction cost of financial institutions and suppliers.

In this case, organizations create costly bureaucratic and hierarchical structures to coordinate and control both internal activities as contracts. As a result, there is the institutionalization of management routines to coordinate efficiency in procurement transactions and inventory, while the financial institutions lend themselves to provide liquidity and minimize business risks. For example, the control of the cash conversion cycle becomes necessary because both buyers and sellers articulate its terms of client-suppliershareholders agreements, so as to meet the desired level of liquidity by the manager.

At this conjuncture, transaction costs are based on: (1) the behavioral assumptions of bounded rationality and opportunism of agents; and (2) the dimensions and/or characteristics of transactions such as frequency, asset specificity, and uncertainty. The factors on the demand side of TC such as frequency of purchases on the type of product purchased and the behavior of the consumer market are determinants of TC which may affect the liquidity of the firm. Moreover, the decision to internalize the activities of lending on credit sales may involve costly actions because the company is faced with many uncertainties about the credit quality of the customer, and, as a result, incurs in transaction cost to obtain information of the credit bureau, of the SPC (Service Protection of Credit in Brazil) and others source before hiring the operation. This is because there are hidden informations (AKERLOF, 1970) from 
customers that are difficult for firms to access, both ex-ante and ex-post for sale. In this case, as higher as it is the uncertainty, higher will be the probability that customers will not pay their debts at maturity, thus increasing the transaction cost and the cash deficit, which contributes to the firm delaying payment of TC. However, the financial costs implicit in this type of delinquency in underdeveloped and emerging credit markets (default interest, penalties, and other costs of collection) are more onerous and can compromise the capital return of the company demanding TC.

\subsection{AGENCY THEORY}

As argued by Berle and Means (1932), separation of the function of managing the control needs a corporate governance structure because of potential conflicts of interests arising from the principal-agent relationships (ROSS, 1973). The mitigation of these conflicts generates "agency costs" to the major due to the asymmetry of information among agents (JENSEN; MECKLING, 1976). These costs arise because of incomplete alignment of interests between the parties to a contract. Smaller companies are confronted with various difficulties to access credit markets outside traditional banking for reasons of both adverse selection and moral hazard (RICE; STRAHAN, 2010). Etiennot, Preve, and Sarria-Allende (2012) provided evidence that these problems are even more serious when the financial and capital markets of the country are less developed as Brazil and the company is smaller. In this case, agency costs of debt are expected to be higher for smaller firms.

Antov and Atanasova (2007) noted that the opacity of information in companies not listed in the stock exchange is the main reason for the financial market to restrict these companies's access to external funds, due to the presence of high costs of asymmetric information resulting from ex-post moral risk arising from potential hidden actions (AKERLOF, 1970) of the buyer and non-identifiable ex-ante by seller. Among the potential hidden actions in the business environment is the non-payment of the debt on the contracted date to the suppliers. In such situations, the issues inherent to informational asymmetry, adverse selection and moral hazard, may have a relatively large effect when companies are young (with little historical information) and small, which may explain why they find it difficult to obtain loans in the traditional credit market (PETERSEN; RAJAN, 1994).

In the context of MSEs, the focus of agency relationships is no longer between shareholder and administrator but involves other actors: for example, customers who require credit for purchases over time or suppliers that offer TC as a tool for sales and encourage them hiring financial banking. As a result of information asymmetry in contracts, agency 
problems arise in two categories: adverse selection and moral hazard. Adverse selection occurs ex-ante while moral hazard involves actions ex-post to hiring. MSEs are considered high-risk agents and are therefore suffer of rationing capital because of financial constraints in the institutional credit due to the opacity of market information. In this situation, the supplier makes the adverse selection of these firms to supply them with goods, even though there is the possibility of moral hazard with potential chance of the customer do not pay its commercial debits.

Costs of bank debt agency are higher than those of TCs because the high frequency of contact with customers generates an informational advantage of suppliers over banks. Berger, Espinosa-Vega, Frame, and Miller (2005) postulated that there is a direct relationship between information asymmetry and a firm's use of short-term debt. In addition, Brockam, Martin, and Unlu (2010) emphasised that hiring short-term debt disciplines the behavior of managers, which reduces agency conflicts and may reduce borrowing costs when good and new companies are disclosed, but exposes firms to liquidity risk due to inefficient liquidation of debt when refinancing is not possible (DIAMOND, 1991). In this case, the firms are likely to delay payment of CCs for lack of cash.

The size, the length of the firm's activity, and the frequency of use of external financing are proxies used to capture the elements of adverse selection models. In line with the guidelines of Myers and Majluf (1984), firms with higher growth opportunities are subject to higher managerial agency costs because there is private information of managers about the expansion projects that foreign investors are only partially aware of.

In models of moral hazard smaller firms are subject to higher levels of default TC's because access to the credit market is limited. In this study, the frequency of late payment to suppliers is the chosen expedient for assessing the risk of financial crime by the company. The ratio of forward purchases (a proxy for the demand for TC) captures both issues of transaction cost and adverse selection problem.

\section{DATA AND METHODS}

\subsection{DATA COLLECTION PROCEDURE}

Considering the objective of this study and the absence of public databases, I carried out a survey with managers and financial executives of companies about short-term financial management practices. The units of analysis were organizations not listed on Securities, Commodities and Futures Exchange of the State São Paulo (BM\&FBOVESPA). The companies, of all sizes, were based in 32 Brazilian cities - 65\% in the State of São Paulo and 
$35 \%$ in the State of Minas Gerais. The classification of the companies by size followed the pattern (number of employees) of the Brazilian Service of Support for Micro and Small Enterprises (SEBRAE). This design allowed the formation of a unique and original database of 554 non-financial companies.

The sampling technique was non-probabilistic of the type for convenience. The data collection was cross-sectional, between 2008 and 2010, with three waves. Difference's tests among samples was conducted by analyze of variance (ANOVA) for continuous variables and Kruskal-Wallis's tests for ordinal variables. The null hypothesis of difference among the averages of the samples was not rejected at a significance level of $5 \%$. Thus, this procedure minimises the existence of statistical bias between samples, allowing them to be aggregated for analysis. The instrument for data collection was a structured questionnaire by Howorth and Westhead (2003) that was reverse translated and adapted to the Brazilian context. I conducted the pre-test of the adjusted version of the questionnaire with eight managers to check if the writing and understanding of each question was clear.

The interviewer conducted the completion of the questionnaires personally as the interviewee answered the questions. The average time to complete the questionnaire was 15 minutes. Cases with missing or inconsistent data were eliminated from the database. Only profit organizations participated in the analysis. The variables associated with late payments of commercial credits selected in this study are based on theoretical aspects of transactions cost and agency theories.

\subsection{VARIABLES}

The Table 1, at following lists the variables, definitions, and measurement metric of model. 


\begin{tabular}{|c|c|c|c|}
\hline Variables & Mnemonic & Interpretation & Measurement scale \\
\hline $\begin{array}{l}\text { Payment delay to } \\
\text { suppliers }\end{array}$ & LATE & $\begin{array}{l}\text { Paying the supplier after the due } \\
\text { date previously agreed between } \\
\text { buyer and seller }\end{array}$ & $\begin{array}{l}\text { Ordinal: } 1=\text { always delayed } \\
\text { to } 9=\text { never delayed }\end{array}$ \\
\hline Company uptime & AGE & $\begin{array}{l}\text { Interval of time from the } \\
\text { foundation up to the date of the } \\
\text { interview }\end{array}$ & Continuous: years \\
\hline $\begin{array}{l}\text { Cash conversion } \\
\text { cycle }\end{array}$ & $\mathrm{CCC}$ & $\begin{array}{l}\text { Average net length, arising from } \\
\text { the management of accounts } \\
\text { receivable, inventories, and } \\
\text { accounts payable }\end{array}$ & Continuous: days \\
\hline $\begin{array}{l}\text { Punctuality of } \\
\text { payments from } \\
\text { customers }\end{array}$ & ONTIME & $\begin{array}{l}\text { Average history of collecting the } \\
\text { receivables portfolio on the due } \\
\text { date }\end{array}$ & $\begin{array}{l}\text { Continuous: average ratio of } \\
\text { the last } 12 \text { months between } \\
\text { amounts received from } \\
\text { customers at maturity and the } \\
\text { total value of the receivables } \\
\text { portfolio }\end{array}$ \\
\hline Credit purchases & PURCHASE & Demand for TC from suppliers & $\begin{array}{l}\text { Continuous: average ratio for } \\
\text { the last } 12 \text { months of credit } \\
\text { purchases and total purchases }\end{array}$ \\
\hline Growth & GROWTH & $\begin{array}{l}\text { Importance of sales growth in the } \\
\text { past three years }\end{array}$ & $\begin{array}{l}\text { Ordinal: } 1=\text { unimportant to } 9 \\
=\text { very important }\end{array}$ \\
\hline $\begin{array}{l}\text { Bank external } \\
\text { financing }\end{array}$ & EXFIN & $\begin{array}{l}\text { Frequency of use of five sources } \\
\text { of bank funds in the last three } \\
\text { years }\end{array}$ & $\begin{array}{l}\text { Ordinal: } 5=\text { never used any } \\
\text { of the sources of funds to } 25 \\
\text { = very frequent use. }\end{array}$ \\
\hline
\end{tabular}

Table 1 - Variables, interpretation, and measurement scale

Payment delay: The frequency of payment delay of commercial loans in companies is the dependent variable of the estimated ordinal logit model. A company delays payment of an obligation to the supplier when it does not honour the terms agreed in the contract. This financial crime can be linked to factors and organizational characteristics widely supported by the literature on moral hazard. This is a proxy for a moral hazard model. At the following, discuss each of up explanatory variables comprising the empirical model.

Uptime and size: Organizational reputation is an important construct for companies to access the financial system. The literature shows that agency cost of debt are lower for larger companies and that have been longer in operation, allegedly, have accumulated more resources and real guarantees to honour their commitments and have more access to the bank credit market. In this study, the variables size and uptime are the proxies that represents the elements of transaction cost and agency theories. Alphonse, Ducret, and Séverin (2004) 
analysed data from small U.S. businesses and found evidence that TC used by companies helped improve the business's reputation and show the credit quality of the firm, and thereby facilitated access to new debt/bank loans. The uptime variable is new in this study. Hypothesis 1 is formulated from these arguments:

Hypothesis 1: The uptime of the company is negatively associated with late payments

Cash conversion cycle (CCC): The variable CCC is also new in this study. The decision to include it arises from its nature as a measure of liquidity of the company (EBBEN; JOHNSON, 2011). The theory of liquidity (CUNÃT, 2007) states, where the availability of cash ensures its perpetuation in the market and the growth of organizations in a healthy way. The CCC variable measures the time interval between the date of receipt of credit sales and the date of payment of suppliers, and is the best indicator of performance that shows the operating efficiency of the firm in managing accounts payable, inventory, and accounts receivable. This variable is a proxy measure of the efficiency of working capital management (DELOOF, 2003). The higher the value of this variable, the higher the value of working capital required to finance the operations of the companies. In addition to this reasoning, Pike and Cheng (2001) found signs that companies that delay payments to suppliers more frequently do so because their cash cycle is long, demanding more funds to support the operation.

It is possible that companies with longer CCC have greater chances of delaying the payment of TC compared to those that operate with short financial cycles. Thus, the following hypothesis is formulated:

Hypothesis 2: The duration of the CCC of the company is directly associated with the delay of liabilities to suppliers

Punctuality of payment on maturity: This variable indicates the level of timely payment of the customers who received credit from companies in forward purchases. It reports to the monthly average ratio in the past 12 months between receiving on the contracted date and the total amount of accounts receivable forecast. When this ratio is low, the uncertainty of the inputs of cash flow increases and the chance of not honouring obligations to the supplier is greater. This information may be useful to investors in assessing the risk of granting new funds. The late payment to suppliers can also keep a negative connection with the low levels of punctuality of payments from clients, thus establishing a transmission 
channel of delays on financial commitments, causing a domino effect (WYNARCZYK, 2000) in the supply chain. Thus, the following hypothesis was established:

\section{Hypothesis 3: The punctuality of the receivables portfolio is negatively associated} to the delay of payments to suppliers

Credit purchases: This variable is a proxy of demand for commercial loans for moral hazard and adverse selection models. Companies with little access to bank credit market frequently fulfill their capital needs (PETERSEN; RAJAN, 1997) from partner suppliers from the business chain operations. In addition to liquidity needs and strategic use to encourage sales, the demand for TC can be directly affected by the proportion of sales on credit made to customers (PIKE; CHENG, 2001), since Micro, Small and Medium Enterprises are companies with limited access to bank credit, and they begin to rely more on financing from suppliers than banks. As stated by Preve and Sarria-Allende (2010, p. 100), the relationship with the supplier is a strategic aspect for clients, because "the knowledge that suppliers might provide financing when it is needed most has clear implications for how a firm will set its financing mix during normal times". These authors also argue that the availability of TC is more stable than bank loans, and this contributes to strengthen both customers and suppliers to the use of credit as the long-term business relationship. The volume of purchases over time can indicate the quality of the credit of the enterprise, the relationship degree with the supplier, and the buyer's market power. As additionally, a greater volume of registers of pay bills may be associated with a decrease in the chance of delaying their financial commitments to suppliers.

Hypothesis 4: The proportion of purchases on credit is negatively associated to the payment delay to suppliers

Growth: Growth was measured according to the perceived importance, by the leader of this event, of the pace of historical expansion of the firm. This variable is a proxy for adverse selection models. According to the foundations of the theory of agency, the agency cost managerial is expected to be higher for firms with high growth opportunities (TITMAN; WESSEL, 1988), because of the high levels of private information asymmetry between insiders of firms not listed and outside investors (JENSEN; MECKLING, 1976). In this context, the greater the desire for company growth, the greater the pressure for funds to finance working capital due to increased operating activity to win markets and greater transaction costs. However, the sample firms can't access the credit market for foreign capital, 
which increases the chances of the company delaying payment to suppliers. The hypothesis derived from this argument is that:

Hypothesis 5: The desire to grow is positively associated with delayed payments to suppliers

External financing: The proxy chosen to capture the use of debt for financial leverage was the frequency of use of the main lines of banking resources available in the domestic financial market. This variable shows itself relevant because the empirical literature on TC documents the hypothesis of complementarity between these two sources. Thus, domestic evidence shows that traded companies with more access to external funding sources also extend more TC to their customers (SCHIOZER; BRANDO, 2011; PALOMBINI; NAKAMURA, 2012).

According with Myers (1977), the use of short-term debt minimises agency costs of debt such as underinvestment and asset substitution (JENSEN; MECKLING, 1976) by making renegotiation more frequent and fit as a mechanism to discipline managers that reduces agency conflicts between managers and shareholders. As a consequence, transaction costs can reduce, allowing contracting of institutional credit for the firm to obtain liquidity and meet its obligations to suppliers. So one might expect an inverse association between access to loans and late payments.

In this study, the institutional lines of credit most commonly available in the financial market were overdraft, guaranteed accounts, check and bill cashing, working capital loans, and financing by Brazilian National of Economic and Sustainable Development Bank (BNDES). The research was based in an ordinal scale of the use of the most common credit lines in Brazil, where the value of 25 corresponded to frequent use of the five available sources of funding (as mentioned above), while the value of 5 corresponded to non-use. Each resource line had the same weight in calculating the average value added of frequency of use of external sources of funding. Therefore, the following assumption was idealised:

Hypothesis 6: Firms that make more use of lines of credit are negatively associated with payment delays

\subsection{METHOD}

The empirical model was estimated by applying multivariate logit regression models to find the factors that are significantly associated with delayed payment to suppliers. Choice models are developed from economic theories of random utility, where classification models (e.g., 
classifying severity levels of financial delinquency) are developed by minimising classification errors with respect to the x's and categorical levels y. This phenomenon is particularly true in a TC supply where finance delinquency is more common. It is usually estimated using maximum likelihood. The use of the ordinal logit method (hereafter OLM) is justified in the multiplecategory case (late payment severity on different levels in this study), which is considered ordinal in nature.

In statistics, an OLM is a generalization of the popular logit analysis to the case of more than two discrete outcomes of an ordinal or polytomous dependent variable. The OLM is one of many models subsumed under the rubric of generalized linear models for ordinal data. The model is based on the assumption that there is a latent continuous outcome variable or index and that the observed ordinal outcome arises from discretising the underlying continuum into j-ordered groups. The thresholds in Statistical Package Social Science estimate these cutoff values. In this study, the underlying relationship (latent) can be characterized as

$$
y^{*}=\alpha_{\mathrm{i}}+\mathbf{x}_{\mathrm{ki} \cdot} \cdot \beta_{\mathrm{k}}+\varepsilon_{\mathrm{i}}
$$

where:

$\alpha$ is the intercept;

$y^{*}$ is the exact but unobserved continuous dependent variable (management's attitude about late payment level in firms);

$\mathbf{x}$ is the vector of independent variables or characteristics operational, demographics of firms, or specific attributes that the decision-maker chooses;

$\beta$ is the vector of regression coefficients which wish to be estimated; and

$\varepsilon$ is the error term that is supposed to follow logistic distribution.

Then the OLM technique uses the observations or choice on y (ordinal categories of response), which are a form of censored continuous data on $y^{*}$, to fit the parameter vector $\beta$. In this case, the model for the latent variable $\left(y^{*}\right)$, along with category thresholds, can determine the cumulative probability distribution of $\mathrm{y}: \operatorname{Pr}\left(\mathrm{Y}_{\mathrm{i}} \leq \mathrm{J}\right)=\operatorname{Pr}\left(y_{i}{ }^{*} \leq \mu_{\mathrm{j}}\right)$. If the errors follow the similar logistic distribution, then the ordered logit or proportional-odds model is:

$$
\begin{aligned}
& \qquad \operatorname{Logit}\left[\operatorname{Pr}\left(Y_{i} \leq J\right)\right]=\left[\frac{\operatorname{Pr}\left(Y_{i} \leq j\right)}{\operatorname{Pr}\left(Y_{i}>J\right)}\right]=\alpha_{j}-\alpha-X_{i 1} \beta_{1}-\ldots \ldots . . .-X_{i k} \beta_{k} \\
& \text { for } j=1,2, \ldots \ldots, m-1 .
\end{aligned}
$$




\section{RESULTS}

\subsection{SAMPLE}

The sample comprised 554 companies of varying sizes, being $51.6 \%$ micro, $37 \%$ small, $5.2 \%$ average, and $6.1 \%$ large companies, showing that the size distribution of companies has positive asymmetry, consistent with the geographic population of the companies. When you separate the data relating to the practice of delaying payments, you find that $53.4 \%$ of the companies frequently delayed payment to vendors. The null hypothesis of binomial distribution ratio was supported $(\mathrm{p}<.001)$. Table 2 , following, shows the relative distribution and the cumulative responses of the leaders on the routine of financial delinquency.

Table 2 - Frequency of Payment Delay to Suppliers by Label

\begin{tabular}{ccccccccccc}
\hline Score & $\mathbf{1}$ & $\mathbf{2}$ & $\mathbf{3}$ & $\mathbf{4}$ & $\mathbf{5}$ & $\mathbf{6}$ & $\mathbf{7}$ & $\mathbf{8}$ & $\mathbf{9}$ \\
\hline$\%$ & 3.6 & 4.0 & 6.3 & 3.6 & 5.2 & 4.3 & 10.5 & 15.9 & 46.6 \\
\% Accumulated & 3.6 & 7.6 & 13.9 & 17.5 & 22.7 & 27.0 & 37.5 & 53.4 & 100.0 \\
\hline
\end{tabular}

Note: The scale had labels with scores ranging from 1 for frequent delays to 9 for never delaying payments to suppliers. The companies with a score of 9 were reclassified as group 0 (non-defaulting) and the others as belonging to the group of offenders.

As can be seen, there are different degrees of severity (label 1: very high and label 8: very low) for this event. One way to better understand this variation and its association with the characteristics of the companies is to reduce the scale of responses. In this study, eight labels were combined and nested, in ascending order, in pairs, and I reclassified them in four groups according to the severity levels of delaying obligations to suppliers. Table 3, following, sets the groups and their frequency responses.

Table 3 - Frequency of Payment Delay by Group

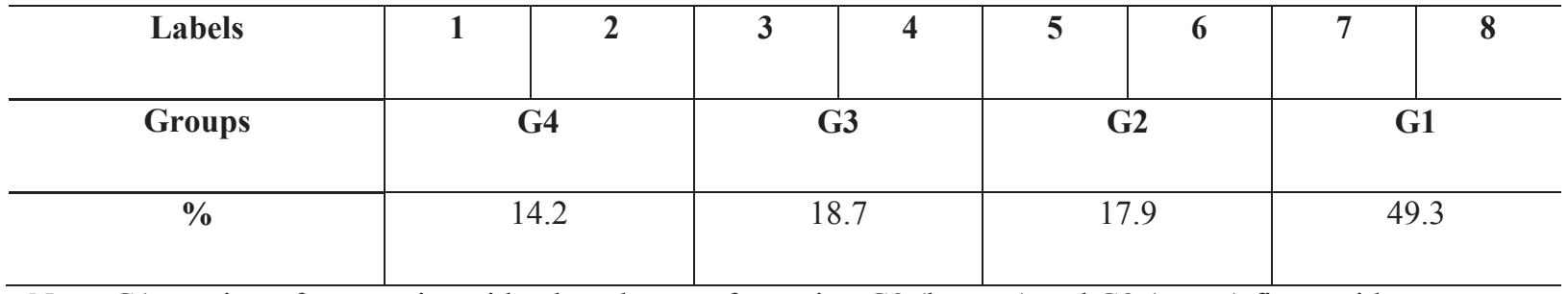

Note: G1 consists of companies with a low degree of severity, G2 (bottom) and G3 (upper) firms with an intermediate degree and G4 firms showing a high degree.

The panel shown in Table 4, following, describes the characteristics of independent variables of the OLM according to the severity levels of the delay or non-payment. 


\subsection{DESCRIPTIVE STATISTICS}

Table 4 -Descriptive Analysis

\begin{tabular}{|c|c|c|c|c|c|c|}
\hline & $\mathrm{N}$ & Minimum & Maximum & Average & $\begin{array}{l}\text { Standard } \\
\text { deviation }\end{array}$ & Symmetry \\
\hline \multicolumn{7}{|c|}{ Group 0: Non-defaulting } \\
\hline AGE & 258 & 1 & 117 & 16.12 & 12.96 & 2.75 \\
\hline PURCHASE & 258 & 0 & 100 & 48.06 & 37.69 & .03 \\
\hline $\mathrm{CCC}$ & 258 & 5 & 180 & 31.57 & 20.61 & 3.11 \\
\hline ONTIME & 258 & 5 & 95 & 41.94 & 25.67 & .53 \\
\hline \multicolumn{7}{|l|}{ Group 1: low severity } \\
\hline AGE & 146 & 2 & 73 & 16.39 & 13.39 & 1.83 \\
\hline PURCHASE & 146 & 0 & 100 & 51.00 & 36.02 & -.05 \\
\hline $\mathrm{CCC}$ & 146 & 7 & 132 & 34.66 & 20.10 & 2.27 \\
\hline ONTIME & 146 & 2 & 95 & 41.80 & 24.63 & .39 \\
\hline \multicolumn{7}{|c|}{ Group 2: bottom average } \\
\hline AGE & 53 & 2 & 36 & 12.19 & 8.55 & 1.31 \\
\hline PURCHASE & 53 & 0 & 100 & 51.30 & 35.39 & -.22 \\
\hline $\mathrm{CCC}$ & 53 & 5 & 75 & 31.47 & 16.25 & .75 \\
\hline ONTIME & 53 & 10 & 95 & 47.11 & 23.41 & .29 \\
\hline \multicolumn{7}{|l|}{ Group 3: upper average } \\
\hline $\mathrm{AGE}$ & 55 & 2 & 69 & 12.55 & 13.24 & 2.17 \\
\hline PURCHASE & 55 & 1 & 98 & 55.98 & 32.94 & -.46 \\
\hline $\mathrm{CCC}$ & 55 & 4 & 90 & 29.76 & 13.17 & 1.87 \\
\hline ONTIME & 55 & 5 & 95 & 43.25 & 25.72 & .52 \\
\hline \multicolumn{7}{|l|}{ Group 4: very high } \\
\hline AGE & 42 & 1 & 54 & 14.43 & 11.48 & 1.51 \\
\hline PURCHASE & 42 & 0 & 100 & 54.52 & 35.17 & -.22 \\
\hline $\mathrm{CCC}$ & 42 & 6 & 60 & 27.26 & 10.62 & .60 \\
\hline ONTIME & 42 & 5 & 95 & 43.71 & 26.31 & .60 \\
\hline
\end{tabular}

Source: Elaborated by the author 
The frequency distributions of the explanatory variables have asymmetry to the right, except for forward purchases. In this situation, most companies are micro and small sized, relatively mature, with $75 \%$ of them taking up to 36 days to recover the capital invested in current assets and $60 \%$ of customers who pay their credit purchases on time. With regard to financing by commercial loans, $75 \%$ of the sample companies buy up to $90 \%$ of stock on credit.

Two ordinal variables - growth and external financing - complete the analysis. The modal value equal to 9 , which corresponds to the very important label in the growth scale, shows that the desire to grow prevails among the leaders. There is evidence in the literature showing that the use of TC positively affects access to banking resources. However, and opposite this notation, the predominant low use of institutional credit lines of among companies in the sample (mode $=5$, corresponding to the non-use of bank credit lines) was observed. This information can partly explain the practice of financial delinquency in the purchasing companies. Of the organisations that contract financing operations, $75 \%$ of them used short and medium-term credit lines.

\subsection{ORDERED LOGIT REGRESSION}

The model specified aims to estimate the probability of companies taking one of the groups according to a set of independent variables. The explanatory variables used to predict the probabilities of the enterprise, where each company would belong to one specific group as shown here after according its variables:

$$
y_{i}^{*}=\beta_{0}+\beta_{1} A G E_{i}+\beta_{2} C C C_{i}+\beta_{3} \text { ONTIME }_{i}+\beta_{4} \text { PURCHASE }_{i}+\beta_{5} \text { GROWTH }_{i}+\beta_{6} \text { EXFIN }_{i}+e
$$

Where:

$y_{i}^{*}=$ unobserved late payment level

$y_{i}=$ declared value by manager

$y_{i}=0$ if $y^{*} \leq 0$, indicating the firm do not delay payment to suppliers

$y_{i}=1$ if $0 \leq y^{*}<\mu_{1}$, indicating the delinquency financial risk is low

$y_{i}=2$ if $\mu_{1} \leq \mathrm{y}^{*}<\mu_{2}$, indicating the delinquency financial risk is bottom - medium

$y_{i}=3$ if $\mu_{2} \leq \mathrm{y}^{*}<\mu_{3}$, indicating the delinquency financial risk is upper - medium

$y_{i}=4$ if $\mu_{3} \geq y^{*}$, indicating the delinquency financial risk is high 
$\mu_{1}, \mu_{2}$ and $\mu_{3}$ are jointly estimated threshold values which determine the delinquency finance level of a firm.

Brant's test of parallel lines was not rejected ( $\mathrm{p}$-value $<1 \%$ ). The validity of the model was verified by statistical tests on the main measures of the logistic evaluation. In estimations by means of logistic models, Hosmer and Lemenshow (1989) recommended that the ratio between sample size and the amount of measured variables in a study be greater than 10 . In the present investigation, this parameter was $\approx 79$. The model chi-square $\left(\chi^{2}\right)$ to test the overall relationship between the dependent and independent variables was significant at the level of $p$-value $<.001$, thus validating the proposed model $\left(\chi^{2}=68.00\right.$; d.f. 32$)$. Further, the relationship robustness tests between group members and utility of the logistic model, to assess the accuracy of classification, were significant, thus supporting the validity of the model. The Nagelkerke statistic for the pseudo- $\mathrm{R}^{2}$ was $32 \%$.

Table 5, following, presents the results of estimates of the ordered logit regression model.

Table 5 -Ordinal Logistic Model

\begin{tabular}{|c|c|c|}
\hline Explanatory variables & Coefficient & T ratio \\
\hline AGE & -0.028 & $2.88^{* *}$ \\
\hline $\mathrm{CCC}$ & 0.001 & 0.27 \\
\hline ONTIME & 0.010 & $3.73^{* *}$ \\
\hline PURCHASE & 0.002 & 0.23 \\
\hline GROWTH & -0.131 & $2.87 *$ \\
\hline EXFIN & 0.063 & $8.04^{* * *}$ \\
\hline Constant & $-3.19(8,32)^{* *}$ & \\
\hline$\chi^{2}$ & $85^{* * * *}(\mathrm{~g} .1=32)$ & \\
\hline
\end{tabular}

Note: This table shows the results of ordinal logistic regression. The method used for calculation of the regression coefficients was the maximum likelihood. Values in parentheses represent the Wald statistic. The symbols $* * *$, and $* * *$ indicate statistical significance at $10 \%, 5 \%$, and $1 \%$, respectively.

The hypothesis $\mathrm{H}_{1}$ tests the negative association between company uptime (AGE) and delay in payments according to agency theory. The evidence suggests, at a significance level of $5 \%$, that companies with less uptime delays more its payment than the non-defaulting ones, thus supporting the prediction. The negative sign indicates that, as the firm remains in operation, the likelihood that the company will become a financial of fender reduces. This result corroborates with the results from Camargos, Araújo, and Camargos (2012) of 
companies that contracted credit with a public financial institution in Minas Gerais State (Brazil). In these circumstances, the theory of organizational reputation seems relevant for companies in this sample.

Surprisingly, and contrary to the hypothesis postulated in $\mathrm{H}_{3}$, the evidence (p-value $<.05)$ suggests that delinquent companies have a higher proportion of customers who pay their credit purchases on time than the non-defaulting companies. This result is the opposite of what Howorth and Reber (2003) found for UK companies. This may mean that manager of firms this sample may be using the cash to fund the investment in accounts receivable or to pay banks due to the endemic indebtedness in companies of this size and not to honor its obligations to suppliers.

The evidence of the variables PURCHASE (proxy for demand of TC) and CCC are also curious for not having significant discriminating power in this model. The direction of coefficients are positive but not significant. Thus, hypothesis $\mathrm{H}_{2}$ and $\mathrm{H}_{4}$ were not supported.

There are indications $(\mathrm{p}$-value $<.10)$ that firms that desire to grow more are smaller delinquent than that of non-defaulting. This result is contrary to the hypothesis postulated by $\mathrm{H}_{5}$, which is based on the theory of agency, information asymmetry, and transaction cost.

Hypothesis $\mathrm{H}_{6}$, which negatively associates the use of external to financial delinquency, was not supported in this study. The direction of the coefficients is opposite to what was presumed. The results show that companies that delay payments to suppliers use more shortterm external funds than the non-defaulting. The positive coefficient of this variable (p-value $<.01$ ) shows that an increase in the use of bank financing sources increases the risk of the firm becoming delinquent. Camargos, Araújo, and Camargos (2012) believe that this can happen because companies have to compromise a higher percentage of revenues for the payment of the funding installments, and the company has a greater need to generate cash, and not all can do it. As a consequence, they delay the payment of commercial debts. This mechanism confirms the theory of demand for extra funding, and thus extends the credit received from trading partners unilaterally.

A plausible explanation for this finding may be in the companies' difficulty in accessing capital in larger volumes or the long-term to finance its operations, and also in the high cost of capital transactions in Brazil. It is also possible that bank financing is used by MSEs only eventually, or in a worst case scenario to cover the mismatch of cash over short periods (CARVALHO, 2012). In this context, the signalling theory of using TC acts adversely against 
trading supplier partners, i.e. the bank loans are intended for other priorities or the rollover of short-term debt. Thus, the results support the fundamentals of credit rationing established for developed markets. It is feasible to think that other management variables not considered in this study may have influenced these controversial findings.

Finally, the estimated coefficients of the three threshold variables are all statistically significant ( $\mathrm{p}$-value $<1 \%$ ), indicating that the use of the four category ordered probit model for financial delinquency is warranted.

Table 6 - Probability and Marginal Probability of Getting Specific Level Severity (y)

\begin{tabular}{ccc}
\hline Level severity & $\mathrm{p}(\mathrm{y})(\%)$ & $\begin{array}{c}\partial \mathrm{p}(\mathrm{y}) / \partial \text { NON-LATE } \\
(\%)\end{array}$ \\
\hline $\mathrm{y}=1$ & 6.92 & -31.86 \\
$\mathrm{y}=2$ & 12.95 & -8.26 \\
$\mathrm{y}=3$ & 46.04 & 5.67 \\
$\mathrm{y}=4$ & 34.09 & 44.45 \\
\hline
\end{tabular}

Source: Elaborated by the author

These marginal probabilities show that firms with a higher level of financial delinquency increase their probability to be in group $4(44.45 \%)$ or $3(5.67 \%)$ and decrease their probability to be in group $2(-8.26 \%)$ or $1(-31.86 \%)$. As is evident from Table 6 , a great majority of enterprises that make delays payment are in group $3(46.04 \%)$ or $4(34.09 \%)$.

\section{CONCLUSIONS}

The aim of this study is to identify the organizational factors associated with late payments of TC in companies not listed on the stock exchange. The financial delinquency negatively impacts the companies's cash management. This happens to a greater extent in those companies with financial difficulties and also helps to generate uncertainty in the business environment of a country. Under these conditions, opportunistic attitudes can affect the image and compromise the reputation of the delinquent company and transaction and TC costs. As a result, companies may lose competitiveness and have their performance threatened.

The evidence shows that smaller companies with little uptime - i.e. those with little reputation with investors and suppliers - are associated with a greater likelihood of delayed payments of TCs.

Regarding the sources of financing, the results indicate the presence of a paradox of the theory of informational advantage of the supplier on the institutional investor. In other words, 
information superiority of the seller imposes a critical issue of adverse selection on them, because there is the liquidity risk of the contracted credit. In these circumstances, the use of TC as an additional source of funds becomes increasingly important for delinquent companies, given their dependence on capital for the continuity of the business in the market.

The contributions of this study are that it generates new knowledge on this type of moral hazard in companies not listed on stock exchanges in emerging markets and exposes the factors associated with late payment of TC.

Future research could study the behavior of the delay in payment of TC according to the economic sector of activity and the size of companies. Another line of research would be to quantify the transaction costs of this event in developing markets and find out the factors that determine the choice of the supplier who will not receive at maturity.

\section{REFERENCES}

AKERLOF, G. A. The market for "lemons": quality uncertainty and the market mechanism. The Quarterly Journal of Economics, v. 84, n. 3, p. 488-500, 1970.

ALPHONSE, P.; DUCRET, J.; SÉVERIN, E. When trade credit facilitates access to bank finance: evidence from US small business data. Social Science Research Network, 2004. Disponível em: $<$ http://papers.ssrn.com/sol3/papers.cfm?abstract_id=260064>. Acesso em: 20 Jan. 2011.

ANTOV, D. S.; ATANASOVA, C. V. Trade credit financing: how expensive is it really? Social Science Research Network, 2007. Disponível em:

$<$ http://papers.ssrn.com/sol3/papers.cfm?abstract_id=260064>. Acesso em: 20 jan. 2013.

BERGER, A. N. et al. Debt maturity, risk, and asymmetric information. The Journal of Finance, v. 60, n. 6, p. 2895-2923, Dec. 2005.

BERLE, A., MEANS, G. The modern corporation and private property. New York: Macmillan, 1932.

BROCKMAN, P.; MARTIN, X; UNLU, E. Executive compensation and the maturity structure of corporate debt. The Journal of Finance, v. 65, n. 3, p. 1123-1161, Jun. 2010.

CAMARGOS, M. A.; ARAÚJo, E. A. T.; CAMARGOS, M. S. A inadimplência em um programa de crédito de uma instituição financeira pública de Minas Gerais: uma análise utilizando regressão logística. REGE - Revista de Gestão, v. 19, n. 3, p. 473-492, 2012.

CARVALHO, C. J. Um ensaio em gestão de capital de giro em micros e pequenas empresas. 2012. 205 p. Tese (Doutorado em Administração de Empresas) - Escola de Administração de Empresas de São Paulo da Fundação Getúlio Vargas, São Paulo, 2012. Disponível em: < http://bibliotecadigital.fgv.br/dspace/handle/10438/9923>. 
CARVALHO, C. J.; SCHIOZER, R. F. Gestão de capital de giro: um estudo comparativo entre práticas de empresas brasileiras e britânicas. RAC-Revista de Administração Contemporânea, v. 16, n.4, p. 518-543. 2012.

COASE, R. The nature of the firm. Economica, v. 4, n. 16, p. 386-405, 1937.

CUÑAT, V. Trade credit: suppliers as debt collectors and insurance providers. The Review of Financial Studies, v. 20, n. 2, p. 491-527, 2007.

DELOOF, M. Does working capital management affect profitability of Belgian companies? Journal of Business Finance \& Accounting, v. 30, n. 3, p. 573-587, 2003.

DIAMOND, D. Monitoring and reputation: the choice between bank loans and directly placed debt. Journal of Political Economy, v. 99, n. 4, p. 689-721, 1991.

EBBEN, J. J.; JOHNSON, A. C. Cash conversion cycle management in small companies: relationships with liquidity, invested capital, and firm performance. Journal of Small Business and Entrepreneurship, v. 24, n. 3, p. 381-396, 2011.

ETIENNOT, H.; PREVE, L. A.; SARRIA-ALLENDE, V. Working capital management: an exploratory study. Journal of Applied Finance, v. 1, p. 162-175, 2012.

HOSMER, D.; LEMESHOW, S. Applied logistic regression. New York: John Wiley \& Sons, 1989.

HOWORTH, C.; REBER, B. Habitual late payment of trade credit: an empirical examination of UK small companies. Managerial and Decision Economics, v. 24, p. 471-482, 2003.

HOWORTH, C. A.; WESTHEAD, P. The focus of working capital management in UK small companies. Management Accounting Research, v. 14, p. 94-111, 2003.

JENSEN, M. C.; MECKLING, W. C. Theory of the firm: managerial behavior, agency costs and ownership structure. Journal of Financial Economics, n. 3, p. 305-360, 1976.

MYERS, S. C.; MAJLUF, N. Corporate financing and investment decisions when firms have information that investors do not have. Journal of Financial Economics, v. 13, n. 2, p. 187 221. 1984.

MYERS, S. C. The determinants of corporate borrowing. Journal of Finance Economics, v. 5, p. 147-175, 1977.

PALOMBINI, N. V. N.; NAKAMURA, W. The determinant factors of working capital management in the Brazilian market. RAE-Revista de Administração de Empresas, v. 52, n. 1, p. 55-69, 2012.

PETERSEN, M. A.; RAJAN, R. G. The benefits of lending relationships: evidence from small business data. The Journal of Finance, v. 49, n. 1, p. 3-37, Mar. 1994.

;. Trade credit: theories and evidence. The Review of Financial Studies, v. 10, n. 3, p. 661-691, August 1997. 
PIKE, R. H.; CHENG, N. S. Credit management: an examination of policy choices, practices and late payment in UK companies. Journal of Business Finance and Accounting, v. 28, n. 7-8, p.1013-1042, 2001.

PREVE, L.; SARRIA-ALLENDE, V. Working capital management: financial management association survey and synthesis series. New York: Oxford University Press, 2010.

RICE, T.; STRAHAN, P. E. Does credit competition affect small-firm finance? The Journal of Finance, v. 65, n. 3, p. 861-889, Jun. 2010.

ROSS, S. A. The economic theory of agency: the principal's problem. American Economic Review, v. 63, n. 2, p. 134-139, 1973.

SCHIOZER, R. F.; BRANDO, J. A. P. A oferta de trade credit pelas empresas brasileiras de capital aberto. Revista Brasileira de Finanças, v. 9, n. 4, p. 585-612, 2011.

TITMAN, S.; WESSEL, R. The determinants of capital structure choice. Journal of Finance, v. 43, n. 1, p. 1-19, 1988.

WILLIAMSON, O. E. Transaction cost economics: the governance of contractual relations. Journal of Law and Economics, v. 22, n. 2, p. 233-261, 1979.

The economics of organization: the transaction cost approach. American Journal of Sociology, v. 87, n. 3, p. 548-577, 1981.

WYNARCZYK, P. Late payment of commercial debts (interest) act 1998: an overview. Regional Studies, v. 34, n.1, p. 87-89, 2000. 